\title{
Microfinance in Peru as Part of the Strategy of an International Investment Fund
}

\author{
Carmelo Intrisano $^{1} \&$ Anna Paola Micheli ${ }^{2}$ \\ 1 Professor of Corporate Finance, Department of Economy and Law, University of Cassino, Italy \\ ${ }^{2}$ Research Fellow and Adjunct Professor in Corporate Finance, University of Cassino and Southern Lazio, \\ Cassino, Italy \\ Correspondence: Carmelo Intrisano, Sant’Angelo Road, Cassino, Italy. E-mail: c.intrisano@unicas.it
}

Received: July 9, 2015

doi:10.5539/ijef.v7n8p281

\begin{abstract}
This paper arises from the idea that in the current conditions of the credit crunch, the Microcredit can be a solution for small businesses that find it increasingly difficult to obtain credit from the banking system and also an opportunity of investment for international investors which want invest in this sector. However, for realize it there must be a system of specialized microcredit institutions and a critical mass of financial need that justifies the action also of investors, including international. Hence the idea of this survey on microfinance in Peru where we analyze the system of Microcredit and estimate, among other things, the financial needs of the institutions of Microcredit.
\end{abstract}

Keywords: microcredit, carry trade, investment fund, international strategy

\section{Introduction}

Among Latin American countries, Peru has a widespread system of microfinance institutions (MFIs), each with its own characteristics in terms of business, legal status and financial structure. The study confirms that the rates charged on microcredit are higher interest rates on lending ordinary, probably for the implicit risk in customers, for the high financial costs and the high operational costs associated with microcredit and the need, in the generality of MFIs, to compensate for the lack of funding sources at low cost, which are deposits. Peru, like other countries is a real market supply financial environment for SMEs. It can count on the particular conditions of the financial market and on a large network of institutions and at the same time is an opportunity for investment for international players. To demonstrate this, after a literature review, we estimated the financial requirement of MFIs that represents the potential investment for an international investment fund. In particular methodologically for each Microcredit Institutions we carried out an analysis of the financial structure, reconstructing the values of loans, deposits and equity capital and calculating the following indicators:

1) Net requirement of the loans portfolio $=$ Credits - Deposits - Equity

2) Net requirement ratio $=($ Loans - Deposits - Equity $) /$ Loans

These indicators allow to identify those potential companies where international investment fund will direct its operations. The hypothesis assumed in this paper, namely the analysis of investment strategies in a mutual fund that collects financial resources on international markets, to employ in Peru MFIs, it must be ensured by the existence of conditions that justify carry trades operability. In other words, first it must verify that the expected losses on the exchange are more than offset by gains on the expected differential in interest rates. In line with most of the empirical evidence on the marketplace, we consider the average results as a proxy of the expected results, second it must verify the risk profile of the Country. Microfinance investment funds have significantly grown in the last ten years, mainly led by MFIs searching for a diversified range of funding sources and by private investors. In term of risk the economic framework is positive given that, despite the uncertainty of the international economic context, Peru has experienced five years of sustained growth. So in 2013 the annual growth rate of GDP of Peru $(5.8 \%)$ has been about 3.5 percentage points that of the world (2.2\%) and Latin America (2.5\%) and nearly 6 points the rate in Europe $(0.1 \%)$. Peru also ranks among the Latin American countries with lower inflation, a rate slightly above the average of the world (2.6\%) and 1.4 
percentage points higher than the rate of inflation in Europe. For the internal business system, Peru favors, with specific legislation, competitiveness, formalization and development of micro-enterprises representing 94.2\% (1,270,009 units) national entrepreneurship. Politically, Peru boasts a condition essentially stable since the government of President Humala, which ends in July 2016, enjoys widespread support in the country in light of the achievements of his economic action in the last decade.

In essence, the economic framework, leading to express an opinion certainly positive, especially compared to other Latin American countries, as confirmed by the ratings expressed by international agencies, such as BBB+ by Standard \& Poor's; A3 rating from Moody's; BBB + is the rating by Fitch.

\section{Literature Review}

The recent literature on micro finance is mainly based on its interactions with the institutional environment, social and economic (Ahlin et al., 2011; Cull et al., 2013; and Vanroose Espallier, 2013) while there are few studies that have attempted to explain the reasons for its spread. Navajas and Tejerina (2006) analyze the mode of access to financial services in Latin America and the Caribbean starting with the record operating data of the Microfinance Institutions (MFIs). Vanroose shows that Peruvian MFIs have had a great expansion in the last ten years, especially in the districts with the highest levels of development. Navajas et al. (2006) provide a risk analysis related to the field of micro-analyzing the portfolios of MFIs in six countries of' Latin America (Bolivia, Colombia, Ecuador, El Salvador, Nicaragua, Peru) using the risk-reward model in consideration of the agreements Basel, concluding that the activities of micro finance can be a profitable business. The field of micro finance in the years 2004/2008 was characterized by high growth rates that have supported the development process especially in rural areas (Chen et al., 2010), this despite the difficult access to finance makes it difficult for MFIs meet the increase in demand (Bogan, 2012). Swanson (2008) in his work estimates a potential demand of 250 billion dollars compared with an offer of 25 billion dollars (Dieckmann, 2007), therefore, the issue of how to fund the MFI has become important (Bogan, 2012). Some paper analyze the currency risk hedging method which can be from a empirically (Priberny \& Dorfleitner, 2013) that from a theoretical point of view (see, for example Holden, P., \& Holden, S., 2004; Crabb, 2004; Featherston et al., 2006). The use of on foreign currency debt as a funding instrument for MFIs has already been addressed in the literature (Caballero \& Krishnamurthy, 2003). Allayannis et al. (2003) analyze the financial structure and the relative performance of the MFI East Asia funded through foreign currency debt.

They state that the differential in interest rates is a potential funding instrument. In recent years the carry trade has drawn attention to the economic literature (K. Kinsgergely, 2010; Rebelo et al., 2008; Galati et al., 2007; Brunnermeier et al., 2009) and Fornari and Anzuini (2012) showed that shocks can exchange influence the level of the differential in interest rates and the level of exchange rates making the carry trade profitable in the short term. However no author focused on the dynamics of relative to the benefits that the foreign currency debt can have on an MFI. Carsten Kuisata, Christopher Pribernya, Demonstrate a positive influence on the financial performance of the MFIs' share of FCD, Whereas social performance has a weak positive impact only for Asian countries. The activity of the carry trade may result in further profit on the appreciation of the high-yielding currency. This phenomenon makes further profitable activity of carry trade, but is a violation of the condition of equality discovery of interest rates (UIP-Uncovered Interest Rate Parity; Kisgergely, 2010; Brunnermeier et al., 2008; Burnside et al., 2007).

The issue of the analysis of market efficiency in microfinance investment funds is considered, from different authors, important. For example, if the market is efficient, it is allow a flow of funds to each MFI which might prevent MFIs from reaching their major clients, that is, the poor people. Recently, microfinance has been increasingly seen as the new investment opportunity by global investors. Since the second part of 1990s, however, some leading MFIs facing the necessity of raising more capital due to rapid loan growth have sought to transform into commercial organizations in order to attract the money they need. Meanwhile, international private investors have increasingly focused on microfinance because of its high repayment rates and stable returns, and they have significantly increased investment in MFIs, especially large-scale MFIs (Inoue \& Hamori, 2010). As regard the possible attractiveness of microfinance for investors, there are only a few papers. Ahlin and Lin (2006) point out that the macroeconomic environment is a significant determinant of MFI performance, which questions the relevance of investments in microfinance in order to reduce portfolio risk. However, they also show that MFI success is for a substantial part determined by MFI-specific factors. Gonzalez (2007), says that microfinance may provide attractive opportunities for portfolio diversification. Microfinance investment funds can therefore be powerful tools in the continued growth of MFIs. Over the last few years, these institutions have set up an increasing number of investment structures to fund MFIs. Goodman (2010) identifies three types of investment fund: quasi-commercial microfinance investment funds, microfinance 
development funds and commercial microfinance investment funds, and three broad categories of financial products made available to MFIs, Equity or quasi-equity participations, Loans, purchase of bonds, Certificates of Deposit, and Guarantees. The introduction of private sector institutional investors seeking full market returns. These mainstream commercial investors, most located in Western Europe and the USA, are driving the opening of capital markets to microfinance. Krauss and Walter (2008) has shown that because of low correlation to market cycles, microfinance could potentially offer significant diversification benefits and reduce portfolio volatility. Galema, Lensink, and Spierdjk (2009) conclude that MFIs from Latin America, or microfinance and rural banks may yield more efficient portfolios. In contrast, adding MFIs from Africa or microfinance NGOs to a benchmark portfolio of international assets does not seem beneficial for a mean-variance investor.

\section{The Analysis of Financial System}

The financial system of Peru presents great opportunities because the demand for credit and financial services is considerably higher than supply (Source: Info Foreign Markets). Following the balance at end of period, in thousands of Nuevo Sol, in December 2013 and October 2014, of the direct credit of the financial system to the private sector, distinguished by Borough (Table 1).

The rules relevant to banks and financial companies find their source in the Law n. 26702 (Ley General System financiero y system of organic follow the Superintendencia de Banca y Seguros del). In particular, the Superintendencia de Banca, Seguros y Fondos de Pensiones de Administradoras Privadas (SBS) is the autonomous entity, created by the Peruvian Constitution, with the function of supervising the entire financial system and authorize activities that involve collection of money from the audience.

Table 1. Balance at end of period: the direct credit of the financial system to the private sector by region

\begin{tabular}{lcc}
\hline \multicolumn{1}{c}{ Regions } & Dec. 2013 & Oct. 2014 \\
\hline Amazonas & 306,436 & 318,820 \\
Ancash & $2,448,358$ & $2,642,380$ \\
Apurímac & 522,402 & 580,609 \\
Arequipa & $7,556,102$ & $8,104,616$ \\
Ayacucho & 736,057 & 822,903 \\
Cajamarca & $2,203,164$ & $2,397,984$ \\
Callao & $5,079,031$ & $5,799,970$ \\
Cusco & $3,350,693$ & $3,677,721$ \\
Huancavelica & 171,440 & 187,153 \\
Huánuco & $1,042,761$ & $1,151,702$ \\
Ica & $3,219,272$ & $3,348,645$ \\
Junín & $3,329,712$ & $3,547,663$ \\
La Libertad & $6,320,324$ & $6,610,721$ \\
Lambayeque & $4,216,270$ & $4,582,894$ \\
Lima & $136,942,337$ & $153,536,574$ \\
Loreto & $1,614,422$ & $1,813,671$ \\
Madre de Dios & 490,628 & 464,940 \\
Moquegua & 610,489 & 635,412 \\
Pasco & 378,531 & 411,636 \\
Piura & $5,103,683$ & $5,390,896$ \\
Puno & $2,628,726$ & $2,743,898$ \\
San Martín & $1,835,603$ & $1,897,165$ \\
Tacna & $1,625,565$ & $1,705,364$ \\
Tumbes & 591,396 & 605,034 \\
Ucayali & $1,169,112$ & $214,199,926$ \\
TOTAL & $193,492,513$ & \\
\hline & & . \\
\hline
\end{tabular}

Source: Central Reserve Bank of Peru.

On the basis of the Annual Report 2013, published by the Central Reserve Bank of Peru, it deduce the following information about the liquidity, credit, deposits, the change of insolvency, the profitability indicators of the 
Peruvian financial system. In 2013 the liquidity in the private sector continued to grow, but with a lower rate than the previous year, due to a more moderate growth in economic activity. It can be seen in fact in 2013 a growth rate of 11.3 percent against 14.1 percent in 2012. By contrast, there was a reduction in the rate of growth of deposits, which rose from 13.0 percent in 2012 to 11,4 percent in 2013.

Table 2. Deposits and liquidity in terms of absolute value and growth rate

\begin{tabular}{lcccc}
\hline & \multicolumn{2}{c}{ Millions (Pen) } & \multicolumn{2}{c}{ Growth rate $(\%)$} \\
\hline & $\mathbf{2 0 1 2}$ & $\mathbf{2 0 1 3}$ & $\mathbf{2 0 1 2}$ & $\mathbf{2 0 1 3}$ \\
Deposits & 147,760 & 164,566 & 13.0 & 11.4 \\
Liquidity & 182,044 & 202,595 & 14.1 & 11.3 \\
\hline
\end{tabular}

Source: Our elaboration on Central Reserve Bank of Peru.

In particular, in 2013 the deposits of individuals grew at a higher rate (16.9 percent) compared to deposits of legal entities (2.3 percent). In terms of currencies, individuals showed a greater preference for activities in Nuevo Sol, while legal entities have shown a greater propensity for activities in US dollars.

Table 3. Deposits from individuals and Legal entities in terms of absolute value and growth rate

\begin{tabular}{ccccc}
\hline \multirow{2}{*}{ Deposits } & \multicolumn{2}{c}{ Millions } & \multicolumn{2}{c}{ Growth rate(\%) } \\
\cline { 2 - 5 } & $\mathbf{2 0 1 2}$ & $\mathbf{2 0 1 3}$ & $\mathbf{2 0 1 2}$ & $\mathbf{2 0 1 3}$ \\
\hline Deposits from individuals of which: & 91,868 & 107,384 & 15.2 & 16.9 \\
in Nuevo Sol & 60,517 & 71,246 & 23.7 & 17.7 \\
in US dollars & 11,197 & 12,906 & 1.6 & 15.3 \\
Legal entities of which: & 55,892 & 57,182 & 9.5 & 2.3 \\
$\quad$ in Nuevo Sol & 27,735 & 26,550 & 26.8 & -4.3 \\
in US dollars & 10,056 & 10,940 & -3.5 & 8.8 \\
Total of which: & 147,760 & 164,566 & 13.0 & 11.4 \\
in Nuevo Sol & 88,252 & 97,796 & 24.7 & 10.8 \\
in US dollars & 21,253 & 23,846 & -0.8 & 12.2 \\
\hline
\end{tabular}

Source: Our elaboration on Central Reserve Bank of Peru.

For liquidity, the most affected sector was the segment of liquidity in domestic currency, whose annual growth rate declined from 23.1 percent in 2012 to 10.8 percent in 2013.

Table 4. Private deposits in terms of absolute value and growth rate

\begin{tabular}{lcccc}
\hline \multirow{2}{*}{\multicolumn{1}{c}{ Private Deposits }} & \multicolumn{2}{c}{ Millions (Pen) } & \multicolumn{2}{c}{ Growth rate(\%) } \\
\cline { 2 - 5 } Overmight deposits & $\mathbf{2 0 1 2}$ & $\mathbf{2 0 1 3}$ & $\mathbf{2 0 1 2}$ & $\mathbf{2 0 1 3}$ \\
\cline { 2 - 5 } Savings deposits & 25,244 & 26,584 & 17.4 & 5.3 \\
Term deposits & 26,935 & 30,958 & 20.2 & 14.9 \\
Total & 36,073 & 40,255 & 34.3 & 11.6 \\
\hline
\end{tabular}

Source: Our elaboration on Central Reserve Bank of Peru.

This slowdown was influenced by expectations about a depreciation of the Nuevo Sol against the dollar, which led to a re-composition of the currencies in the deposit market. In addition, a greater reduction was observed in the segment of deposits (from 34.3 percent in 2012 to 11.6 percent in 2013). Conversely, liquidity in foreign currency showed an improvement, switching from -0.9 percent to 12.4 percent. Much of this increase occurred in the second half of the year due to expectations about a depreciation of the Nuevo Sol against the dollar. A more dynamic growth rates compared to 2012 was highlighted by the savings and time deposits. In fact, the annual rate of time deposits grew by -7.9 percent in 2012 to 13.9 percent in 2013. 
Table 5. Foreign currency deposits in terms of absolute value and growth rate

\begin{tabular}{lcccc}
\hline \multirow{2}{*}{ Foreign currency deposits the private } & \multicolumn{2}{c}{ Millions (Pen) } & \multicolumn{2}{c}{ Growth rate (\%) } \\
\cline { 2 - 4 } Overmight deposits & $\mathbf{2 0 1 2}$ & $\mathbf{2 0 1 3}$ & $\mathbf{2 0 1 2}$ & $\mathbf{2 0 1 3}$ \\
Savings deposits & 7,552 & 8,483 & 8.2 & 12.3 \\
Term deposits & 5,369 & 5,873 & -0.8 & 9.4 \\
Total & 8,331 & 9,491 & -7.9 & 13.9 \\
\hline
\end{tabular}

Source: Our elaboration on Central Reserve Bank of Peru.

The growth rate of total credit to the private sector shrank for the third consecutive year, falling from 15.4 percent in 2012 to 13.2 percent in 2013.

Table 6. Credit in private sector in terms of absolute value and growth rate

\begin{tabular}{lcccc}
\hline \multirow{2}{*}{ Credit in the private sector } & \multicolumn{2}{c}{ Millions (Pen) } & \multicolumn{2}{c}{ Growth rate (\%) } \\
\cline { 2 - 5 } & $\mathbf{2 0 1 2}$ & $\mathbf{2 0 1 3}$ & $\mathbf{2 0 1 2}$ & $\mathbf{2 0 1 3}$ \\
\hline Legal entities of which: & 113,451 & 128,374 & 13.3 & 13.2 \\
Corporate and large companies & 50,811 & 61,798 & 8.5 & 21.6 \\
Medium-sizedenterprises & 30,792 & 33,982 & 18.4 & 10.4 \\
Small businesses & 31,847 & 32,594 & 16.7 & 2.3 \\
Individuals of which: & 62,620 & 71,004 & 19.4 & 13.4 \\
Consumption & 36,786 & 40,983 & 15.3 & 11.4 \\
Mortgages & 25,834 & 30,021 & 25.7 & 16.2 \\
\hline
\end{tabular}

Source: Our elaboration on Central Reserve Bank of Peru.

More specifically, the growth rate of credit to businesses fell from 13.3 percent in 2012 to 13.2 percent in 2013. Similarly, the growth rate of personal loans decreased from 19.4 percent to 13.4 percent. In corporate lending the greatest increase in demand for loans was registered, in order, in trade, manufacturing and mining.

Table 7. Credit in private sector in terms of absolute value and growth rate

\begin{tabular}{lcccc}
\hline Total credit by sector & \multicolumn{2}{c}{ Millions (Pen) } & \multicolumn{2}{c}{ Growth rate (\%) } \\
\cline { 2 - 5 } & $\mathbf{2 0 1 2}$ & $\mathbf{2 0 1 3}$ & $\mathbf{2 0 1 2}$ & $\mathbf{2 0 1 3}$ \\
\hline Agriculture and livestock & 5,388 & 5,904 & 18.2 & 9.6 \\
Fishing & 1,512 & 1,625 & -7.6 & 7.5 \\
Mining & 4,700 & 6,731 & -7.6 & 43.2 \\
Manufacturing industry & 24,269 & 27,387 & 5.2 & 12.8 \\
Electricity, Gas and Water & 6,683 & 6,085 & 21.4 & -9.0 \\
Buildings & 3,847 & 4,194 & 27.9 & 9.0 \\
Trade & 29,498 & 33,187 & 17.2 & 12.5 \\
Hotels and Restaurants & 2,914 & 2,977 & 20.8 & 2.2 \\
Transport and Roads & 9,374 & 10,375 & 9.7 & 10.7 \\
Real Estate and Business & 12,713 & 13,635 & 21.8 & 7.3 \\
Other & 12,551 & 16,273 & 17.6 & 29.7 \\
Total & 113,451 & 128,374 & 13.3 & 13.2 \\
\hline
\end{tabular}

Source: Our elaboration on Central Reserve Bank of Peru.

The financial indicators of Peruvian banks deteriorated in 2013 in the sizes indicated in the table. 
Table 8. Financial indicatorob Peruvian banks (\%)

\begin{tabular}{lcc}
\hline & 2012 & 2013 \\
\hline Overdue loans / gross issuance & 1.8 & 2.1 \\
Portfolio of high risk / gross issuance & 2.8 & 3.1 \\
Loans Fund / Portfolio at high risk & 142.5 & 131.6 \\
Return on Equity (ROE) & 22.4 & 21.2 \\
Return on Assets (ROA) & 2.2 & 2.0 \\
\hline
\end{tabular}

Source: Our elaboration on Central Reserve Bank of Peru.

The default rate of large enterprises remained stable at low levels, and increased that of the medium, small and micro enterprises.

Table 9. Banks default rate

\begin{tabular}{lcc}
\hline BANKS: DEFAULT RATE BY TYPE AND SIZE OF DEBTOR $(\boldsymbol{\%})$ & $\mathbf{2 0 1 2}$ & $\mathbf{2 0 1 3}$ \\
\hline & 0.0 & 0.0 \\
Corporate loans & 0.4 & 0.4 \\
Loans to large companies & 2.5 & 3.7 \\
Loans to medium enterprises & 5.3 & 7.3 \\
Loans to small enterprises & 2.7 & 3.6 \\
Lending to micro enterprises & 3.0 & 3.4 \\
Consumer loans & 0.8 & 1.0 \\
Mortgages & 1.8 & 2.1 \\
Total & & \\
\hline
\end{tabular}

Source: Our elaboration on Central Reserve Bank of Peru.

Also indicators of non-banking financial companies showed a deterioration, rising default rates and lower rates of coverage of high-risk portfolio. Specifically, the rural banks Savings showed the highest default rate (7.0 percent in 2013) and the lowest coverage ratios of high-risk portfolio (84.7 per 2013). As for the ROE, all non-banking institutions have reduced their profitability in 2013.

Table 10. Financial indicator non banking companies

\begin{tabular}{|c|c|c|}
\hline & 2012 & 2013 \\
\hline \multicolumn{3}{|l|}{ Overdueloans / grossissuance } \\
\hline Business finance & 4.5 & 5.0 \\
\hline Municipalsavingsbanks & 5.2 & 5.8 \\
\hline Ruralsavingsbanks & 5.4 & 7.0 \\
\hline Edpymes & 4.8 & 4.8 \\
\hline \multicolumn{3}{|c|}{ Loans Fund / Portfolio at high risk } \\
\hline Business finance & 132.2 & 122.5 \\
\hline Municipalsavingsbanks & 108.0 & 105.5 \\
\hline Ruralsavingsbanks & 84.4 & 84.7 \\
\hline Edpymes & 120.0 & 115.2 \\
\hline \multicolumn{3}{|l|}{ ROE } \\
\hline Business finance & 21.6 & 13.5 \\
\hline Municipalsavingsbanks & 14.6 & 12.8 \\
\hline Municipalsavingsbanks & 7.1 & 1.2 \\
\hline Edpymes & 5.7 & 5.0 \\
\hline
\end{tabular}

Source: Our elaboration on Central Reserve Bank of Peru.

According to "Report de estabilidad Financiera", published in November 2014 by the Banco Central de Reserva del Peru, the default rate stood higher levels for the non-banking sector than banks, as it reflects the risk 
associated to the segments in which they operate mainly micro and small enterprises.

Table 1. Rate of insolvency

\begin{tabular}{|c|c|c|c|}
\hline \multicolumn{4}{|c|}{ \% Rate of insolvency } \\
\hline & sept-13 & dec-13 & sept-14 \\
\hline Total system & 3.5 & 3.5 & 3.9 \\
\hline Banks & 3.0 & 3.1 & 3.4 \\
\hline Non-Banks & 7.5 & 7.1 & 8.3 \\
\hline Business finance & 6.4 & 6.4 & 7.1 \\
\hline Municipalsavingsbanks & 8.3 & 7.6 & 8.7 \\
\hline Municipalsavingsbanks & 8.7 & 8.5 & 14.6 \\
\hline Edpymes & 6.4 & 5.5 & 5.5 \\
\hline
\end{tabular}

Source: Our elaboration on Central Reserve Bank of Peru.

\section{The Microfinance Institutions}

Peru has a lot of companies specialized in Microfinance (67 surveyed in this study).

There are banks and financial companies that operate in Microfinance and there are the follwing typical Peruvian Institutios that provide financial services to small and micro enterprises and who are in conditions of poverty: Cajas Municipales de Ahorro y Crédito, Cajas Rurales de Ahorro y Crédito, Entidad de Desarrollo para la Pequeña y microempresa, Cooperatives de ahorro y crédito

The banks in Peru are regulated institutions that offer various financial services. In addition to offering deposit services, banks have begun to offer loans to small and micro enterprises since the early ' 80 . In particular Mibanco, founded in 1998, is the first Peruvian bank focused in microcredit.

The financial companies (EmpresasFinancieras) are regulated institutions that offer general banking and specialized services for micro-enterprises. They are not banking institutions;

The Cajas Municipales de Ahorro y Crédito (CMCAC) are municipal non-banking institutions regulated and owned by the government, that receive deposits and are specialized in lending to small and micro enterprises. Since 2002, they are allowed to operate anywhere and to offer various banking services.

Cajas Rurales de Ahorro y Crédito (CRAC): regulated institutions authorized to receive deposits and to offer all types of loans, but they are not authorized to manage current accounts. They were created in 1992 such as institutions focalized in agriculture. Over the years their work has been extended to financial services for commerce;

Entidad de Desarrollo para la Pequeña y microempresa (EDPYME) is a regulated institution and specialized in loans referred to small and micro enterprise. This institution, unable to raise funds through deposits, uses only its own capital and the funds come from donations.

The Cooperatives de ahorro y crédito are cooperatives monitored by the Federación Nacional de Cooperativas de Ahorro y Crédito del Perú (FENACREP). This particular institution is supervised by the SBS, and it contributes to the socio-economic development of credit unions. The Cooperativa de Ahorro y Crédito is a non-profit organization with the aim of providing, among other financial services, deposits and loans at reasonable rates. Cooperatives are in fact authorized to accept deposits and provide all types of loans;

Moreover the Non Governmental Organizations (NGOs) also operate in Microcredit. A lot of NGOs develop mainly microfinance programs. In Peru, the largest NGOs specialized in microfinance are members of COPEME, a trade association that promotes small and micro enterprises. These NGOs are self-regulated with the assistance of COPEME, which provides them advice on international standards and good governance for the microfinance industry.

Resolution n. 5721997 SBS has added a new category of loans for Microfinance, called loans to micro-enterprise. This resolution has brought to significant expansion of credit to small and micro-enterprises, through the definition of eligible loans to micro-enterprises. These type of loans are direct or indirect loans accorded to natural and legal persons, in order to finance production activities, commerce, service activities. The requirements are:

1) Total assets (without considering real estate) must not exceed $\$ 20,000$; 
2) Q debt in the financial system that does not exceed $\$ 20,000$ or the equivalent in national currency.

Resolution n. 808 of 2003 has modified the definition of credits to micro enterprises (resolution no. 572-97 of SBS), increasing the limit to $\$ 30,000$ of the total debt.

In view of this, the MFIS (Microfinance Institutions) are divided into regulated and unregulated by the Superintendencia de Banca, Seguros y Fondos de Pensiones de AdministradorasPrivadas (SBS).

The SBS, as mentioned earlier, is an independent public entity, which regulates and supervises all institutions of the financial system, including insurance sector and private pension funds sector. Its purpose is to protect savings, insurance and pensions of the general public. The SBS authorizes the organization and functions of all regulated financial institutions. As governor institution has played a key role in the development of regulations for microfinance in Peru. It is a monitoring and regulatory recognized worldwide, whose mission is to protect the public interest by safeguarding the stability, solvency and transparency of monitored systems, promote access for everyone to the financial system and contribute to the system of prevention and detection of money laundering and terrorist financing.

The regulated institutions are subject to the Law n. 26702 of SBS.

According to Article 9 of that law, financial companies are free to indicate the interest rates, fees and expenses for its operations and services. The identification of interest rates by the company must comply with the limits imposed by the Central Bank and, in exceptional cases, with the regulation of its statute. Interest rates, fees and other expenses must be public, according to the rules established by the SBS.

The CajasMunicipales de Ahorro y Crédito and CajasMunicipales de Crédito Popular are also governed by its own laws.

In addition, the subsidiaries must comply with minimum share capital requirement set in Nuevo Sol:

- Banking business: 14,914,000;

- Financial company: 7,500,000;

- Caja Municipal de Crédito Popular: 4,000,000.

We indicate below the limit of 678,000:

- Caja Municipal de Ahorro y Crédito;

- Entidad de Desarrollo a la Pequeña y Micro Empresa;

- Cooperativas de Ahorro y Créditoautorizadas to captarrecursos del público;

- Caja Rural de Ahorro y Crédito.

Table 12. Microcredit institutions for regulatory bodies

\begin{tabular}{cc}
\hline MFIs regulated by SBS & MFIs non-regulated by SBS \\
\hline CMACs & \\
CRACs & Non-Governmental Organizations \\
Financial company & (NGOs) \\
Mibanco & \\
\hline Regulated by FENACREP & \\
Cooperativas de ahorro y crédito & \\
\hline
\end{tabular}

Source: Our elaboration.

On the methodological basis, the analysis on microcredit institutions determines the Net requirement of the loan portfolio and the index of net requirement as shown in the following table: 
Table 13. Net requirement of the loan portfolio and the index of net requirement

\begin{tabular}{|c|c|c|c|c|c|c|}
\hline Microcredit Institutions & Year & $\begin{array}{c}\text { Loans Portfolio } \\
\text { (USD) }\end{array}$ & $\begin{array}{c}\text { Deposits } \\
\text { (USD) }\end{array}$ & $\begin{array}{l}\text { Equity } \\
\text { (USD) }\end{array}$ & $\begin{array}{l}\text { Net requirement of the } \\
\text { loan portfolio (USD) }\end{array}$ & $\begin{array}{c}\text { Index of net } \\
\text { requirement (\%) }\end{array}$ \\
\hline Mentors - PER & 2011 & 255,731 & 0 & $-7,669$ & 263,399 & $103.00 \%$ \\
\hline ASIDME & 2013 & 455,311 & 0 & 994,915 & $-539,604$ & $-118.51 \%$ \\
\hline IDESI La Libertad & 2013 & 804,421 & n.d. & $2,808,500$ & n.d. & n.d. \\
\hline IDESI GRAU & 2012 & 825,075 & 0 & 590,212 & 234,863 & $28.47 \%$ \\
\hline IDER CV & 2011 & $1,394,292$ & 0 & 556,333 & 837,958 & $60.10 \%$ \\
\hline Alternativa Microfinanzas & 2012 & $1,554,792$ & 0 & 540,720 & $1,014,072$ & $65.22 \%$ \\
\hline FOVIDA & 2013 & $2,398,720$ & 0 & $2,196,234$ & 202,486 & $8.44 \%$ \\
\hline MIDE & 2013 & $2,531,951$ & 0 & 937,472 & $1,594,479$ & $62.97 \%$ \\
\hline AMA & 2013 & $2,575,652$ & 0 & $1,177,905$ & $1,397,747$ & $54.27 \%$ \\
\hline EDAPROSPO & 2012 & $2,743,249$ & 6,526 & 896,598 & $1,840,125$ & $67.08 \%$ \\
\hline ADEA Andahuaylas & 2012 & $3,557,712$ & 0 & $3,310,118$ & 247,594 & $6.96 \%$ \\
\hline FINCA - Perù & 2013 & $5,425,562$ & 0 & $4,797,492$ & 628,070 & $11.58 \%$ \\
\hline PRISMA & 2012 & $5,807,082$ & 69,476 & 748,673 & $4,988,933$ & $85.91 \%$ \\
\hline ADRA Perú & 2013 & $6,227,287$ & 0 & $4,556,472$ & $1,670,815$ & $26.83 \%$ \\
\hline CRAC Incasur & 2013 & $6,768,133$ & $9,848,917$ & $1,995,304$ & $-5,076,088$ & $-75.00 \%$ \\
\hline AsociaciónArariwa & 2013 & $7,014,154$ & 0 & $3,638,439$ & $3,375,715$ & $48.13 \%$ \\
\hline EDPYME Credivisión & 2013 & $8,019,777$ & 0 & $2,535,483$ & $5,484,294$ & $68.38 \%$ \\
\hline COOPAC Norandino & 2012 & $8,468,682$ & $2,462,202$ & $2,907,763$ & $3,098,717$ & $36.59 \%$ \\
\hline Manuela Ramos & 2013 & $8,774,994$ & 0 & $6,070,220$ & $2,704,774$ & $30.82 \%$ \\
\hline EDPYME Marcimex & 2014 & $11,381,945$ & 0 & $3,850,752$ & $7,531,192$ & $66.17 \%$ \\
\hline CRAC Sipán & 2013 & $11,482,775$ & $15,496,921$ & $2,970,082$ & $-6,984,228$ & $-60.82 \%$ \\
\hline CRAC Libertadores de Ayacucho & 2013 & $13,126,083$ & $18,628,609$ & $1,816,941$ & $-7,319,467$ & $-55.76 \%$ \\
\hline CRAC Cajamarca & 2013 & $18,078,223$ & $24,476,143$ & $5,646,574$ & $-12,044,494$ & $-66.62 \%$ \\
\hline COOPAC León XIII & 2012 & $18,454,828$ & $15,842,458$ & $12,896,661$ & $-10,284,291$ & $-55.73 \%$ \\
\hline COOPAC San Hilarión & 2013 & $19,999,639$ & $15,935,092$ & $6,503,579$ & $-2,439,032$ & $-12.20 \%$ \\
\hline CRAC Credichavín & 2013 & $20,311,751$ & $42,368,010$ & $3,758,532$ & $-25,814,791$ & $-127.09 \%$ \\
\hline FONDESURCO & 2013 & $20,641,423$ & 0 & $4,020,731$ & $16,620,692$ & $80.52 \%$ \\
\hline EDPYME Alternativa & 2014 & $27,220,855$ & 0 & $5,383,358$ & $21,837,497$ & $80.22 \%$ \\
\hline Pro Mujer - PER & 2013 & $27,940,051$ & 0 & $15,621,046$ & $12,319,005$ & $44.09 \%$ \\
\hline EDPYME Acceso Crediticio & 2014 & $41,915,016$ & 0 & $7,175,235$ & $34,739,781$ & $82.88 \%$ \\
\hline COOPAC Los Andes & 2012 & $33,992,424$ & $27,577,854$ & $7,382,355$ & $-967,784$ & $-2.85 \%$ \\
\hline COOPAC Santo Domingo & 2011 & $34,632,369$ & $31,891,969$ & $6,614,900$ & $-3,874,499$ & $-11.19 \%$ \\
\hline COOPAC San Cristóbal & 2011 & $35,982,988$ & $28,146,926$ & $13,885,642$ & $-6,049,580$ & $-16.81 \%$ \\
\hline CRAC Los Andes & 2013 & $52,246,366$ & $34,038,359$ & $8,095,207$ & $10,112,801$ & $19.36 \%$ \\
\hline COOPAC San Martín & 2012 & $52,273,472$ & $30,442,054$ & $17,076,117$ & $4,755,301$ & $9.10 \%$ \\
\hline EdpymeInversiones La Cruz & 2014 & $57,909,661$ & 0 & $2,132,759,973$ & $-2,074,850,311$ & $-3582.91 \%$ \\
\hline CMAC Del Santa & 2013 & $57,942,734$ & $70,042,589$ & $9,218,541$ & $-21,318,396$ & $-36.79 \%$ \\
\hline F. TFC & 2014 & $58,106,027$ & $107,318,012$ & $256,371,236$ & $-305,583,221$ & $-525.91 \%$ \\
\hline FinancieraNuevaVisión & 2014 & $57,623,925$ & $20,176,105$ & $12,236,092$ & $25,211,728$ & $43.75 \%$ \\
\hline COOPAC Santo Cristo & 2012 & $70,062,213$ & $46,377,151$ & $17,026,765$ & $6,658,296$ & $9.50 \%$ \\
\hline CMAC Paita & 2013 & $72,446,427$ & $77,291,419$ & $11,850,716$ & $-16,695,708$ & $-23.05 \%$ \\
\hline FinancieraQapac & 2013 & $81,975,336$ & $95,992,570$ & $22,771,634$ & $-36,788,869$ & $-44.88 \%$ \\
\hline COOPAC Santa Maria & 2012 & $82,128,853$ & $83,135,363$ & $25,787,465$ & $-26,793,974$ & $-32.62 \%$ \\
\hline FinancieraProempresa & 2014 & $98,435,916$ & $20,263,152$ & $19,572,511$ & $58,600,253$ & $59.53 \%$ \\
\hline Popular SAFI & 2010 & $104,159,478$ & 0 & $452,934,532$ & $-348,775,054$ & $-334.85 \%$ \\
\hline EdpymeCredijet & 2014 & $107,926,705$ & 284,277 & $262,598,365$ & $-154,955,938$ & $-143.58 \%$ \\
\hline CMAC Maynas & 2013 & $113,396,696$ & $119,778,462$ & $19,657,705$ & $-26,039,471$ & $-22.96 \%$ \\
\hline FinancieraEfectiva & 2014 & $121,911,064$ & $64,853,634$ & $35,748,807$ & $21,308,624$ & $17.48 \%$ \\
\hline CRAC Credinka & 2013 & $144,298,180$ & $130,471,405$ & $22,430,937$ & $-8,604,162$ & $-5.96 \%$ \\
\hline EDPYME Raíz & 2014 & $173,009,608$ & 0 & $44,841,308$ & $128,168,300$ & $74.08 \%$ \\
\hline CMCP Lima & 2013 & $190,556,388$ & $233,887,950$ & $37,823,041$ & $-81,154,603$ & $-42.59 \%$ \\
\hline CMAC Ica & 2013 & $240,557,147$ & $273,475,845$ & $36,862,258$ & $-69,780,956$ & $-29.01 \%$ \\
\hline CMAC Tacna & 2013 & $253,519,398$ & $222,427,397$ & $39,901,907$ & $-8,809,905$ & $-3.48 \%$ \\
\hline
\end{tabular}




\begin{tabular}{lcccccc}
\hline CRAC Señor de Luren & 2013 & $274,427,486$ & $297,894,625$ & $30,605,882$ & $-54,073,021$ & $-19.70 \%$ \\
CompartamosFinanciera & 2014 & $315,688,649$ & $61,919,748$ & $45,044,915$ & $208,723,985$ & $66.12 \%$ \\
EDPYME Solidaridad & 2013 & $319,098,975$ & 0 & $118,064,394$ & $201,034,581$ & $63.00 \%$ \\
CMAC Sullana & 2013 & $442,387,320$ & $444,475,147$ & $74,987,782$ & $-77,075,609$ & $-17.42 \%$ \\
CMAC Cusco & 2013 & $444,157,709$ & $413,655,051$ & $91,833,047$ & $-61,330,389$ & $-13.81 \%$ \\
Financiera Confianza & 2014 & $452,661,980$ & $317,858,804$ & $87,787,968$ & $47,015,209$ & $10.39 \%$ \\
CMAC Trujillo & 2013 & $460,318,710$ & $515,977,276$ & $111,723,893$ & $-167,382,459$ & $-36.36 \%$ \\
CMAC Huancayo & 2013 & $464,934,599$ & $417,717,372$ & $81,165,380$ & $-33,948,153$ & $-7.30 \%$ \\
CMAC Piura & 2013 & $666,493,440$ & $776,440,125$ & $102,013,350$ & $-211,960,034$ & $-31.80 \%$ \\
FinancieraEdyficar & 2013 & $937,310,033$ & $435,037,905$ & $129,537,137$ & $372,734,992$ & $39.77 \%$ \\
CMAC Arequipa & 2014 & $944,671,927$ & $988,453,513$ & $145,657,971$ & $-189,439,557$ & $-20.05 \%$ \\
Crediscotia & 2014 & $1,060,587,216$ & $714,599,872$ & $159,138,926$ & $186,848,419$ & $17.62 \%$ \\
MiBanco & 2014 & $1,384,739,594$ & $1,309,821,484$ & $197,354,612$ & $-122,436,502$ & $-8.84 \%$ \\
CRAC Prymera & 2014 & $3,872,480,570$ & $5,186,412,787$ & $876,234,284$ & $-2,190,166,501$ & $-56.56 \%$ \\
\hline
\end{tabular}

Source: Our elaboration.

So, from the summary table above have been excluded those companies that have a negative net borrowing requirement or tending to 0 and the Index of net requirements with values near or below 0. From the MFIs remaining are left out, also, those with loan portfolio of at least $\$ 2$ million.

On this basis, the analysis led to the identification of 20 potential MFIs targets of international fund.

Table 14. Index of net requirement ranking

\begin{tabular}{lccc}
\hline \multicolumn{1}{c}{ MicrocreditInstitutions } & $\begin{array}{c}\text { Loans Portfolio } \\
(\mathbf{U S D})\end{array}$ & $\begin{array}{c}\text { Net requirement of } \\
\text { the loan portfolio }\end{array}$ & $\begin{array}{c}\text { Index of net requirement } \\
(\%)\end{array}$ \\
\hline PRISMA & $5,807,082$ & $4,988,933$ & $85.91 \%$ \\
EDPYME Acceso Crediticio & $41,915,016$ & $34,739,781$ & $82.88 \%$ \\
FONDESURCO & $20,641,423$ & $16,620,692$ & $80.52 \%$ \\
EDPYME Alternativa & $27,220,855$ & $21,837,497$ & $80.22 \%$ \\
EDPYME Raíz & $173,009,608$ & $128,168,300$ & $74.08 \%$ \\
EDPYME Credivisión & $8,019,777$ & $5,484,294$ & $68.38 \%$ \\
EDAPROSPO & $2,743,249$ & $1,840,125$ & $67.08 \%$ \\
EDPYME Marcimex & $11,381,945$ & $7,531,192$ & $66.17 \%$ \\
CompartamosFinanciera & $315,688,649$ & $208,723,985$ & $66.12 \%$ \\
EDPYME Solidaridad & $31,368,545$ & $20,277,494$ & $64.64 \%$ \\
MIDE & $2,531,951$ & $1,594,479$ & $62.97 \%$ \\
FinancieraProempresa & $98,435,916$ & $58,600,253$ & $59.53 \%$ \\
AMA & $2,575,652$ & $1,397,747$ & $54.27 \%$ \\
AsociaciónArariwa & $7,014,154$ & $3,375,715$ & $48.13 \%$ \\
Pro Mujer - PERU & $27,940,051$ & $12,319,005$ & $44.09 \%$ \\
FinancieraNuevaVisión & $57,623,925$ & $25,211,728$ & $43.75 \%$ \\
FinancieraEdyficar & $937,310,033$ & $372,734,992$ & $39.77 \%$ \\
COOPAC Norandino & $8,468,682$ & $3,098,717$ & $36.59 \%$ \\
Manuela Ramos & $8,774,994$ & $2,704,774$ & $30.82 \%$ \\
ADRA Perú & $6,227,287$ & $1,670,815$ & $26.83 \%$ \\
\hline
\end{tabular}

Source: Ourelaboration.

Among the institutions analyzed it showed that some, because of their small size and juridical unregulated, do not provide detailed information on the procedures relating to loans. The following table provides a summary of the main indicators characterizing the 20 companies analyzed. 
Table 15. MFIs financial indicators

\begin{tabular}{|c|c|c|c|c|c|c|c|}
\hline $\begin{array}{l}\text { Microcredit } \\
\text { Institutions }\end{array}$ & $\begin{array}{c}\text { Loans Portfolio } \\
\text { (\$) }\end{array}$ & Deposits (\$) & Equity (\$) & $\begin{array}{c}\text { Net requirement } \\
\text { of the loan } \\
\text { portfolio }(\$) \\
\end{array}$ & $\begin{array}{c}\text { Index of net } \\
\text { requirement } \\
(\%)\end{array}$ & $\begin{array}{l}\text { Loss rate } \\
\text { Portfolio } \\
\text { Loans (\$) } \\
\end{array}$ & $\begin{array}{c}\text { Microcredit } \\
\text { interest rate } \\
(\text { Pen }) \\
\end{array}$ \\
\hline PRISMA & $5,807,082$ & 69,476 & 748,673 & $4,988,933$ & $85.91 \%$ & $-2.56 \%$ & - \\
\hline EDPYME A. Crediticio & $41,915,016$ & 0 & $7,175,235$ & $34,739,781$ & $82.88 \%$ & $0.10 \%$ & $40.26 \%$ \\
\hline FONDESURCO & $20,641,423$ & 0 & $4,020,731$ & $16,620,692$ & $80.52 \%$ & $2.61 \%$ & $43.41 \%$ \\
\hline EDPYME Alternativa & $27,220,855$ & 0 & $5,383,358$ & $21,837,497$ & $80.22 \%$ & $2.17 \%$ & $47.97 \%$ \\
\hline EDPYME Raíz & $173,009,608$ & 0 & $44,841,308$ & $128,168,300$ & $74.08 \%$ & $2.96 \%$ & $38.05 \%$ \\
\hline EDPYME Credivisión & $8,019,777$ & 0 & $2,535,483$ & $5,484,294$ & $68.38 \%$ & $2.18 \%$ & $54.07 \%$ \\
\hline EDAPROSPO & $2,743,249$ & 6,526 & 896,598 & $1,840,125$ & $67.08 \%$ & $0.44 \%$ & $35.33 \%$ \\
\hline EDPYME Marcimex & $11,381,945$ & 0 & $3,850,752$ & $7,531,192$ & $66.17 \%$ & $33.64 \%$ & - \\
\hline CompartamosFin. & $315,688,649$ & $61,919,748$ & $45,044,915$ & $208,723,985$ & $66.12 \%$ & $4.52 \%$ & $67.70 \%$ \\
\hline EDPYME Solidaridad & $31,368,545$ & 0 & $11,091,050$ & $20,277,494$ & $64.64 \%$ & $4.19 \%$ & $48.53 \%$ \\
\hline MIDE & $2,531,951$ & 0 & 937,472 & $1,594,479$ & $62.97 \%$ & $-1.68 \%$ & $42.00 \%$ \\
\hline Financiera Proempresa & $98,435,916$ & $20,263,152$ & $19,572,511$ & $58,600,253$ & $59.53 \%$ & $2.82 \%$ & $37.37 \%$ \\
\hline AMA & $2,575,652$ & 0 & $1,177,905$ & $1,397,747$ & $54.27 \%$ & $6.82 \%$ & - \\
\hline AsociaciónArariwa & $7,014,154$ & 0 & $3,638,439$ & $3,375,715$ & $48.13 \%$ & $5.76 \%$ & $45.15 \%$ \\
\hline Pro Mujer - PERU & $27,940,051$ & 0 & $15,621,046$ & $12,319,005$ & $44.09 \%$ & $2.20 \%$ & - \\
\hline FinancieraN.Visión & $57,623,925$ & $20,176,105$ & $12,236,092$ & $25,211,728$ & $43.75 \%$ & $2.78 \%$ & $42.50 \%$ \\
\hline FinancieraEdyficar & $937,310,033$ & $435,037,905$ & $129,537,137$ & $372,734,992$ & $39.77 \%$ & $2.16 \%$ & $39.23 \%$ \\
\hline COOPAC Norandino & $8,468,682$ & $2,462,202$ & $2,907,763$ & $3,098,717$ & $36.59 \%$ & - & $30 \%$ \\
\hline Manuela Ramos & $8,774,994$ & 0 & $6,070,220$ & $2,704,774$ & $30.82 \%$ & $0.00 \%$ & - \\
\hline ADRA Perú & $6,227,287$ & 0 & $4,556,472$ & $1,670,815$ & $26.83 \%$ & $0.22 \%$ & - \\
\hline
\end{tabular}

\section{Conclusion}

This paper explored the possible economic convenience of microfinance investment funds and, giving a cognitive framework to investors on how to consider microfinance in their asset allocations, in the wake of Kane, Nair, Orozco and Sinha (2005) which contribute to enrich the information framework for assessing the country-specific investment risk of commercial investments in microfinance and identify incentives and disincentives for MFIs to disclosing information important to investors. Ebentreich (2005) analyze microfinance regulation in Peru showing good prospects for investment in the sector. Mendez et al. (2014) in their work underline that Peru is an excellent destination for foreign investment.

In light of the other empirical evidence, the paper concludes that Peru is an attractive country in terms of funding opportunities for micro enterprises on the one hand and an investment opportunity for investors who operate in the field of microfinance on the other hand. Research has shown that there is high interest rates on Microcredit can ensure good profit margins to investors even when they are forced to borrow at rates more burdensome than those average charged on the international market. It states that the Microcredit is financial segment that presents a high risk profile and, therefore, assumes greater return expectations.

\section{References}

Ahlin, C., \& Lin, J. (2006). Luck or Skill? MI Performance in Macroeconomic Context. BREAD Working Paper 132.

Armendáriz, B., \& Szafarz, A. (2011). On Mission Drift of Microfinance Institutions. MPRA Paper No. 31041. http://dx.doi.org/10.1142/9789814295666_0016

Arzuini, A., \& Fornari, F. (2012). Macroeconomic Determinants of Carry Trade Activity. Review of International Economics, 20(3), 468-488. http://dx.doi.org/10.1111/j.1467-9396.2012.01034.x

Assefa, E., Hermes, N., \& Meesters, A. (2013). Competition and the Performance of Microfinance Institutions. Applied Financial Economics, 23(9), 767-782. http://dx.doi.org/10.1080/09603107.2012.754541

Battilana, J., \& Dorado, S. (2010). Building Sustainable Hybrid Organizations: The Case of Commercial Microfinance Institutions. Academy of Management Journal, 53(6), 1419-1440. http://dx.doi.org/10.5465/AMJ.2010.57318391

Bebbington, A. (2004). NGOs and Uneven Development: Geographies of Development Intervention. Progress in 
Human Geography, 28(6), 725-745. http://dx.doi.org/10.1191/0309132504ph516oa

Blossfeld, H. P., \& Rohwer, G. (2002). Techniques of Event History Modelling: New Approaches to Causal Analysis. London, England: Lawrence Erlbaum Associates.

Christen, R. P. (2001). Commercialization and Mission Drift: The Transformation of Microfinance in Latin America. CGAP Occasional Paper 5.

Claessens, S. (2005). Access to Financial Services: A Review of the Issues and Public Policy Objectives. Washington, DC: World Bank. http://dx.doi.org/10.1596/1813-9450-3589

Cull, R., Demirgüç-Kunt, A., \& Morduch, J. (2013). Banks and Microbanks. NYU Wagner Research Paper. http://dx.doi.org/10.2139/ssrn.2232170

Demirgüc-Kunt, A., Beck, T., \& Honohan, P. (2008). Finance for All? Policies and Pitfallsin Expanding Access. World Bank Policy Research Report. Washington, DC: World Bank.

Ebentreich, A. (2005). Microfinance Regulation in Peru: Current State, Lessons Learned and prospects for the Future (Working paper).

Firth, D. (1993). Bias Reduction of Maximum Likelihood Estimates. Biometrika, 80(1), 27-38. http://dx.doi.org/10.1093/biomet/80.1.27

Fouillet, C. (2009). La Construction Spatiale de la Microfinance enInde (Doctoral Thesis). Université Libre de Bruxelles, Belgium.

Galema, R., Lensink, R., \& Spierdjk, L. (2009). International Diversification and Microfinance. Discussion Paper 05/2009-023. http://dx.doi.org/10.2139/ssrn.1509332

Ghosh, S., \& Van Tassel, E. (2008). A Model of Microfinance and Mission Drift (Working Paper). Florida Atlantic University, Department of Economics, Florida.

Gonzalez, A. (2007). Resilience of Microfinance Institutions to National Macroeconomic Events: An Econometric Analysis of MFI asset quality. MIX Discussion Paper no. 1. http://dx.doi.org/10.2139/ssrn.1004568

Gutiérrez-Nieto, B., \& Serrano-Cinca, C. (2010). Factors Influencing Funder Loyalty to Microfinance Institutions. Nonprofit and Voluntary Sector Quarterly, 39(2), 302-320.

Hartman, R. S. (1991). A Monte Carlo Analysis of Alternative Estimators in Models Involving Selectivity. Journal of Business \& Economic Statistics, 9(1), 41-49.

Heckman, J. (1979). Sample Selection Bias as a Specification Error. Econometrica, 47, 153-161. http://dx.doi.org/10.2307/1912352

Hermes, N., Lensink, R., \& Meesters, A. (2009). Financial Development and the Efficiency of Microfinance Institutions (Working Paper). Groningen Universiteit, Groningen.

Holden, P., \& Holden, S. (2004). Foreign Exchange Risk and Microfinance Institutions: A Discussion of the Issues. MicroRate and Enterprise Research Institute.

Kane, S., Nair, D., Orozco, V., \& Sinha, S. (2005). Peru: Microfinance Investment Environment Profile (Working paper).

Khandker, S. R. (1996). Grameen Bank: Impact, Costs, and Program Sustainability. Asian Development Review, 14(1), 97-130.

Krauss, N., \& Ingo, W. (2008). Can Microfinance Reduce Portfolio Volatility?

Madalengoitia, O., \& Saldaña, R. (2010). Amplicación de losServiciosFinancieros en AreasRurales: El Uso de Agencies en LocalesCompartidos con el Banco de la Nación, in Perú: El problema Agrario en Debate, Sepia XIII, Mesa Especial: Finanzas Rurales. Lima, Perù: SEPIA.

Marconi, R., \& Mosley, P. (2005). Bolivia during the Global Crisis 1998-2004: Towards a 'Macroeconomics' of Microfinance. Sheffield Economic Research Paper Series.

McIntosh, C., \& Wydick, B. (2005). Competition and Microfinance. Journal of Development Economics, 78(2), 271-298. http://dx.doi.org/10.1016/j.jdeveco.2004.11.008

Mersland, R., \& Strøm, O. (2009). Performance and Governance in Microfinance. Journal of Banking and Finance, 33(4), 662-669. http://dx.doi.org/10.1016/j.jbankfin.2008.11.009 
Navajas, S., \& Tejerina, L. (2006). Microfinance in Latin America and the Caribbean: How Large is the Market? Sustainable Development Department Best Practices Series.

Pande, R., \& Burgess, R. (2005). Can Rural Banks Reduce Poverty? Evidence from the Indian Social Banking Experiment. American EconomicReview, 95(3), 780-795. http://dx.doi.org/10.1257/0002828054201242

Portocarrero, F. et al. (2003). Estructura de Mercado y Competencia en elMicrocrédito en elPerú. Lima, Perù: Consorcio de InvestigacionEconomica y Social.

Stolzenberg, R. M., \& Relles, D. A. (1997). Tools for Intuition about Sample Selection Bias and Its Correction. American Sociological Review, 62(3), 494-507. http://dx.doi.org/10.2307/2657318

Trivelli, C., Escobal, J., \& Revesz, B. (2009). DesarolloRural en la Sierra: Aportes para el Debate. Lima, Perù: Institute for Peruvian Studies.

Vanroose, A., \& D' Espallier, B. (2013). Do microfinance institutions accomplish their mission? Evidence from the relationship between traditional financial sector development and microfinance institutions' outreach and performance. Applied Economics, 45(15), 1965-1982. http://dx.doi.org/10.1080/00036846.2011.641932

\section{Copyrights}

Copyright for this article is retained by the author(s), with first publication rights granted to the journal.

This is an open-access article distributed under the terms and conditions of the Creative Commons Attribution license (http://creativecommons.org/licenses/by/3.0/). 